\title{
Fusarium oxysporum and $F$. verticillioides associated with damping-off in Pinus spp. ${ }^{1}$
}

\author{
Fusarium oxysporum e F. verticillioides causando damping-off em Pinus spp.
}

\author{
Caciara Gonzatto Maciel $^{2 *}$, Clair Walker², Ricardo Feliciano dos Santos ${ }^{3}$, Marlove Fátima Brião Muniz² \\ and Daniele Lemos Brum²
}

\begin{abstract}
Occurrence of Fusarium spp. is one of the problems, most limiting to growth of seedlings, in nurseries. This pathogen can be transmitted via seeds and causes damages to the seedlings during pre- and post-emergence stages. The present study aimed to identify Fusarium spp. at the species level based on morphological and molecular characteristics and to verify the pathogenicity of these isolates in seeds lots of Pinus elliottii and P. taeda. For this, we used two Fusarium isolates and five lots of Pinus spp. seeds. Morphological characterization was performed based on a key, specific to Fusarium spp. identification, whereas, molecular identification was carried out by amplification and sequencing of the regions from internal transcribed spacer (ITS) and the elongation factor 1- $\alpha$ (tefl). The pathogenicity test was conducted through the contact of the seeds with fungal culture for $48 \mathrm{~h}$, followed by sowing them in sand. The variables evaluated were emergency speed index, percentage of emergency, non-emergency seeds, symptomatic seedlings, and seedling damping-off. One isolate, F1UFSM, was identified as F. verticillioides and another isolate, F2UFSM, was identified as F. oxysporum. Both the isolates were pathogenic to the seeds of Pinus spp., causing a reduction in the percentage of emergence and seedling damping-off.
\end{abstract}

Key words: ITS. Elongation factor (tef1). Pinus taeda. Pinus elliottii.

\begin{abstract}
RESUMO - A ocorrência de Fusarium spp. é um dos problemas mais limitantes em viveiros, esse patógeno pode ser transmitido via semente e causar danos em pré e pós-emergência. O presente trabalho objetivou identificar isolados de Fusarium spp. a nível de espécie e verificar a patogenicidade desses isolados em lotes de sementes de Pinus elliottii e P. taeda. Foram utilizados dois isolados do patógeno e cinco lotes de sementes de Pinus spp. Para caracterização molecular, sequenciaram-se as regiões genômicas: ITS e fator de elongação 1- $\alpha$ (tef1), para morfologia dos isolados utilizaram-se chaves de identificação específica para o gênero Fusarium. O teste de patogenicidade foi realizado através do contato das sementes com a cultura fúngica por 48 horas, seguida de semeadura em areia. As variáveis avaliadas foram: índice de velocidade de emergência, porcentagem de emergência, plântulas sintomáticas e tombamento de plântulas. O isolado F1UFSM foi identificado como Fusarium verticillioides e o F2UFSM como F. oxysporum. Ambos foram patogênicos a P. taeda e P. elliottii, causando redução no percentual de emergência e tombamento de plântulas.
\end{abstract}

Palavras-chave: ITS. Fator de elongação (tef1). Pinus taeda. Pinus elliottii.

\footnotetext{
DOI: $10.5935 / 1806-6690.20170015$

*Autor para correspondência

${ }^{1}$ Recebido para publicação em 30/09/2015 a 12/04/2016

Parte da Tese de Doutorado em Engenharia Florestal da primeira autora, apresentada à Universidade Federal de Santa Maria/UFSM

${ }^{2}$ Departamento de Defesa Fitossanitária, Universidade Federal de Santa Maria, Campus Universitário, Centro de Ciências Rurais Prédio 42, $2^{\circ}$ Piso, Sala 3223A, Santa Maria-RS, Brasil, 97.105-900, caciaragonzatto@gmail.com, clairwalker@gmail.com, marlovemuniz@yahoo.com.br, danielelemosbrum@yahoo.com.br

${ }^{3}$ Departamento de Fitopatologia, Escola Superior de Agricultura “Luiz de Queiroz" USP/ESALQ/USP, Piracicaba-SP, Brasil, ricardofelicianodossantos@gmail.com
} 


\section{INTRODUCTION}

The occurrence of Fusarium spp. is one of the problems that are the most limiting to the growth of seedlings in nurseries. This cosmopolitan pathogen is a native inhabitant of soil and is difficult to control. Several species of Fusarium are associated with seed rot and damping-off of seedlings of Pinus spp., for example, $F$. sambucinum in P. elliottii (MACIEL et al., 2013), $F$. circinatum in $P$. radiata and $P$. pinaster (LANDERAS et al., 2005) as well as $F$. circinatum in $P$. maximinoi, $P$. patula and $P$. tecunumanii (STEENKAMP et al., 2012), and $P$. taeda and P. elliottii (LORI; SALERNO, 2003). Pfenning et al. (2014) identified $F$. circinatum associated with Pinus in Brazil, where this pathogen is considered a quarantine fungus.

F. oxysporum and $F$. verticillioides were observed to be pathogenic to seedlings of $P$. nigra in northwestern Spain, causing damping-off during pre-emergence stage and, therefore, in the reduction of germination potential (MARTÍN-PINTO; PAJARES; DÍEZ, 2008). Because of the diversity of hosts that are compromised by Fusarium, it is necessary to identify the pathogen at the species level in order to facilitate the applicability of control strategies.

In this context, O'Donnell (2000) and Leslie and Summerell (2006) suggested three features of species for identification of Fusarium spp.: morphological, based on the similarity of the observed characters, called morphological markers, biological, based on the sexual compatibility between members of the same species, and phylogenetic, based on the analysis of gene sequences. DNA analysis is an effective tool, rapid and accurate to detection of fungal pathogens to species or strain level (TSUI; WOODHALL; CHEN, 2011), and has been complementing the morphological characterization, giving more credibility to the process of identifying the species.

Considering the above background, the objective of the present study was to identify Fusarium spp. at the species level based on morphological and molecular characteristics and to verify the pathogenicity of these isolates in seeds lots of $P$. elliottii and P. taeda.

\section{MATERIAL AND METHODS}

Seeds of P. elliottii and P. taeda (harvested in 2013) used in this study had their origin in the municipality of Ijui (28 23'16" S e 53 54'54" W), located in the northwest region of Rio Grande do Sul state, Brazil. Five lots were used: two of P. elliottii (Lot 1 and Lot 2) and two of P. taeda (Lot 3 and Lot 4) and a fifth lot P. elliottii (SP1) was from Sao Paulo city, Sao Paulo. For isolation of the pathogen from the lots, seeds were subjected to the "blotter test", whereby, they were incubated for seven days at $25{ }^{\circ} \mathrm{C}$ under a $12 \mathrm{~h}$ light/dark photoperiod; the morphological characteristics of the putative Fusarium colonies on the seeds were observed after this period. The putative colonies were then subcultured on Petri dishes containing potato dextrose agar (PDA) medium supplemented with $0.5 \mathrm{~g} \cdot \mathrm{L}^{-1}$ streptomycin sulfate and incubated under the same conditions mentioned above. The characteristics of the resulting colonies were compared to those described earlier for the genus Fusarium (GERLACH; NIRENBERG, 1982; LESLIE; SUMMERELL, 2006). Monosporic cultures were obtained (Table 1) according to the methodology of Alfenas and Mafia (2007) and stored in the mycological collection of the Laboratory of Plant Pathology, Universidade Federal Santa Maria, Santa Maria, RS, Brazil.

For molecular characterization of the fungal isolates, mycelium and spores were collected from the cultures grown on PDA medium for two weeks under the conditions described in the previous section. DNA from the pathogen was extracted by the cetyltrimethylammonium bromide (CTAB) method (DELLAPORTA; WOOD; HICKS, 1983). Samples of the extracted genomic DNA were used in polymerase chain reaction (PCR) for amplification of internal transcribed spacer (ITS) region of rDNA using the primer pair, ITS1 (5'-TCCGTAGGTGAACCTGCGG$\left.3^{\prime}\right)$ and ITS4 (5'-TCCTCCGCTTATTGATATGC-3') (WHITE et al. 1990.) and the region of elongation factor 1 alpha (tefl) using the primer pair EF1-T (5'ATGGGTAAGGARGACAAGAC-3') and EF1-1567R (5'-ACHGTRCCRATACCACCRATCTT-3') (REHNER; BUCKLEY, 2005). Each PCR mixture contained approximately $1 \mu \mathrm{L}$ DNA, $10 \mu \mathrm{L} 5 \mathrm{X}$ GoTaq Reaction Buffer (Promega, EUA), $1 \mu \mathrm{L}$ dNTPs mixture, $1 \mu \mathrm{L}$ of each primer, $0.2 \mu \mathrm{L}$ GoTaq DNA polymerase (Promega, EUA), and autoclaved MiliQ water to the make the volume to $50 \mu \mathrm{L}$. PCR was performed in a GeneAmp PCR System 2400 (Perkin Elmer, EUA) under the following cycling conditions: $94{ }^{\circ} \mathrm{C}$ for $2 \mathrm{~min}, 40$ cycles of denaturation at $94{ }^{\circ} \mathrm{C}$ for $30 \mathrm{~s}$, annealing at $50{ }^{\circ} \mathrm{C}$ for $2 \mathrm{~min}$, and elongation at $72{ }^{\circ} \mathrm{C}$ for $1 \mathrm{~min}$ followed by a final extension at $72{ }^{\circ} \mathrm{C}$ for $4 \mathrm{~min}$. At the end of the reaction, the PCR products were stored at $4{ }^{\circ} \mathrm{C}$. A negative control, without DNA, was included in the PCR amplifications. After electrophoresis on a $0.8 \%$ agarose gel in $1 \mathrm{X}$ TAE buffer (0.04 M Tris-acetate, $1 \mathrm{mM}$ EDTA) and staining of the gel with ethidium bromide $\left(1 \mathrm{mg} \mathrm{L}^{-1}\right)$, the amplified fragments were visualized under ultraviolet light. A $1 \mathrm{~kb}$ Plus DNA ladder (Invitrogen, USA) was used as the molecular weight marker. The PCR products obtained were purified following the protocol described by Schmitz and Riesner (2006) using polyethylene glycol 6000 (PEG 6000). 
Table 1 - Details of isolates Fusarium spp. utilized in this study

\begin{tabular}{lcccc}
\hline \multirow{2}{*}{ Isolate } & Origin & Collection period (month/year) & \multicolumn{2}{c}{ Access code in GenBank } \\
& & & ITS & TEF1 \\
\hline F1UFSM & Seeds of $P$. elliottii & $04 / 2013$ & KX710194 & KU170704 \\
F2UFSM & Seeds of $P$. taeda & $04 / 2013$ & KX710195 & KU170705 \\
\hline
\end{tabular}

The obtained sequences were compared to those of Fusarium and Gibberella spp. (teleomorph), available in the GenBank. The sequences from the GenBank that showed the highest scores were selected and aligned with the sequences of the amplified products by the ClustalW algorithm. Furthermore, phylogenetic analysis was conducted, adopting the Neighbor-joining method with 1000 replicates in the MEGA program version 4 (TAMURA; DUDLEY; NEI, 2007). The similarity of the nucleotide sequences between the isolates was calculated using the Basic Local Alignment Search Tool-BLAST (http://blast.ncbi.nlm.nih.gov/Blast.cgi).

For morphological characterization, sterilized leaf fragments $\left(\sim 3-5 \mathrm{~mm}^{2}\right)$ of carnation (Dianthus caryophyllus) were infected with colonies of the pure isolates on $2 \%$ culture medium agar (NELSON; TOUSSON; MARASAS, 1983; VENTURA, 1999) and incubated for 25 days at $25 \pm 2{ }^{\circ} \mathrm{C}$ under $12 \mathrm{~h}$ light/dark photoperiod, for scaling and photography of reproductive structures. Thirty conidia were evaluated in the isolates of Fusarium spp. by measuring their length and width. For staining of the culture, mycelia were aliquoted in test tubes containing PDA medium and incubated for 10 days under the conditions specified above. The color was determined visually (front plate) and compared with that described in the literature (LESLIE; SUMMERELL; 2006; NELSON; TOUSSON; MARASAS, 1983).

To determine the average mycelial growth of the isolates, we placed agar-solidified culture medium disks $(12 \mathrm{~mm})$ derived from the plates of the pure cultures in the center of a Petri dish containing PDA medium. The plates were incubated under the conditions specified earlier and the mycelial growth was observed by measuring the diameter of the colony every $24 \mathrm{~h}$ with the aid of a digital caliper, during seven days. The measurements were taken in two diametrically opposed directions. At the end of this experiment, the sporulation of each isolate was determined, by adding $20 \mathrm{~mL}$ of sterile distilled water to each Petri dish and scraping with the handle of a Drigalski spatula; the suspension was filtered through gauze and the concentration (conidia $\mathrm{mL}^{-1}$ ) of conidia was estimated using a Neubauer chamber. Five replicate plates $(90 \mathrm{~mm})$ of each isolate were used for determining the sporulation. The mycelial growth were submitted to regression analysis using the statistic program System Analysis of Variance for Balanced Data (SISVAR 5.3) (FERREIRA, 2010).

The pathogenicity of F1UFSM and F2UFSM isolates in Pinus seeds was determined by inoculating the seeds of five lots of P. elliottii (Lot1, Lot2 and SP1) and $P$. taeda (Lot3 and Lot4) with the pathogens. The seeds used in the tests remained stored in the freezer $\left(-18{ }^{\circ} \mathrm{C}\right)$ for two weeks for breaking their dormancy (BRASIL, 2009). For testing the pathogenicity, initially, the seeds were sterilized with a solution of $70 \%(\mathrm{v} / \mathrm{v})$ alcohol for 30 s and then with a solution of sodium hypochlorite $(1 \% \mathrm{v} / \mathrm{v})$ for 1 minute. They were subsequently washed with sterile distilled water and dried on sterile filter paper. Each treatment used 100 seeds, divided into four replicates of 25 seeds each.

After the incubation period of the fungus (seven days at $25 \pm 2{ }^{\circ} \mathrm{C}$ with a photoperiod of $12 \mathrm{~h}$ light/dark), inoculation was carried out by keeping the seeds in contact with the fungal culture for $48 \mathrm{~h}$ at $25 \pm 2{ }^{\circ} \mathrm{C}$ and $12 \mathrm{~h} \mathrm{light/dark}$ photoperiod. For the control, seeds were exposed only to the PDA medium under the same conditions. After inoculation, the test of emergence in sand was performed, in which the seeds were placed in plastic boxes $(11 \times 11 \times 3.5 \mathrm{~cm})$ containing sifted sand as a substrate; the sand was sterilized by autoclaving for $2 \mathrm{~h}$ (with interval of $24 \mathrm{~h}$ ) 1 atm and $120{ }^{\circ} \mathrm{C}$. The material remained incubated in a temperature-controlled room with a temperature of $25 \pm 2{ }^{\circ} \mathrm{C}$ and with manual irrigation where necessary. Were used four plastic boxes per treatment, and each treatment corresponds to inoculation of Fusarium spp. (F1UFSM or F2UFSM) on lots of Pinus spp. seeds (Lot1, Lot2, Lot3, Lot4 or SP1).

The variables evaluated were: a) emergence speed index (ESI): daily count of emerged seedlings, considered when the hypocotyls were bigger than $1.0 \mathrm{~cm}$, determining the ESI through the equation suggested by Maguire (1962); b) seedling emergence: counting the number of seedlings at 28 days; c) abnormal seedlings symptomatic: seedling with symptoms caused by the Fusarium were checked; d) non-emergence seeds: count of the seeds 
with rotted aspect and of those that had not started the germination process. For all variables, except the ESI, the results were expressed as percentages. When the presence of damping-off was detected, the seedlings were collected and incubated in a moist chamber or placed in Petri dishes with PDA culture medium, with the goal of determining whether the damage was caused by the inoculated fungus, and then re-isolation was performed.

The trials were conducted in a completely randomized design, treatments with four repetitions, and each repetition consisting of one plastic boxes containing 25 seeds. Means comparison was done by Tukey's test at 5\% probability; the software used was SISVAR 5.3 (FERREIRA, 2010).

\section{RESULTS AND DISCUSSION}

In this study, the isolates F1UFSM and F2UFSM were pathogenic to Pinus's seeds. The seedling symptoms began approximately 14 days after inoculation and were described as follows: seed rot and damping off in preemergency and post emergency of seedlings (Figure 1).

Analyzing the values of ESI lots of study, with and without inoculation of Fusarium spp., notes that those who remained in contact with the pathogen before sowing

Figure 1 - Symptoms post-emergence observed in seedlings of Pinus spp. after the inoculation with Fusarium sp.: (A) P. elliottii Lot1 x F1UFSM; (B) P. elliottii Lot2 x F1UFSM; (C) P. elliottii SP1 x F1UFSM (C); and (D) without inoculation - control

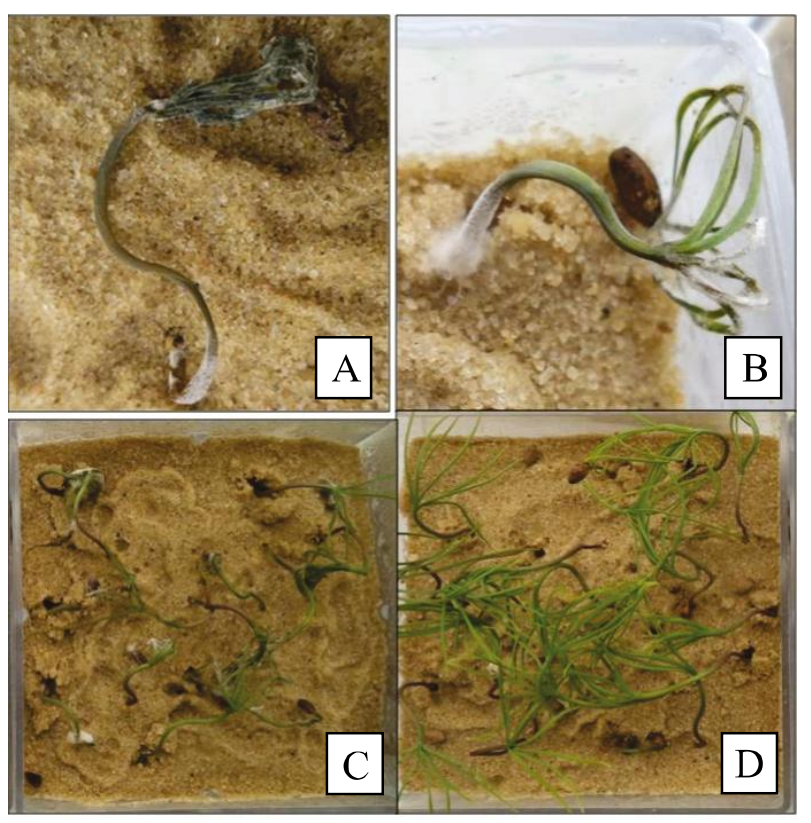

had a lower rate of emergence speed. This means that the average number of seedlings per day decreased due to colonization of seed by the pathogen, thus causing an increase in the inequality of emergence of seeds, associated with reduced vigor. According to the data presented in Table 2 reveals that the isolates were pathogenic seeds of Pinus spp., directly interfering on seedling emergence variable, except for the seeds lot of $P$. elliottii (SP1), where no significant difference was for this variable. In this lot $(P$. elliottii - SP1) the difference was observed for the variables symptomatic seedlings and damping-off in post-emergence when compared with the control treatment. This result may indicate that the presence of the pathogen did not affect the initial formation processes (germination and emergence), but acted in a negative way during seedling development.

The fusariosis, in the seedlings of different Pinus spp., is reported to be an important disease in the nursery causing discoloration of the needles, drying of the apical parts, browning of the roots, growth stagnation (GRIGOLETTI JUNIOR; AUER, 2006), wilting and low seedling-survival rate (MACIEL et al., 2013.), and rot and reduction in the root development (OCAMB; JUZWIK; MARTIN, 2002).

DNA of Fusarium spp. isolates was amplified with primers and sequenced. For the tefl and ITS regions, 677 and 678 bp fragments were amplified, respectively. Both the analyzed regions were effective in the classification of the isolates belonging to the same clade based on the other sequences of Fusarium spp. deposited in the GenBank having high bootstrap values. To construct the phylogenetic tree, based on both the ITS and tefl amplicons, the GenBank accessions that showed the highest coverage $(\geq$ $95 \%$ ) and similarity were chosen $(\geq 98 \%$ ) (Figure 2$)$. The F1UFSM isolate was allocated in the same clade with F. verticillioides (anamorph Gibberella moniliformis), with bootstrap values of 98 and 87, while F2UFSM was grouped with $F$. oxysporum with bootstrap values of 97 and 84, respectively, for ITS and tefl. According to Geiser et al. (2004), tefl has become the most common marker, since it is highly informative among the Fusarium single copy genes. Schoch et al. (2012) emphasized the importance of specific markers for Fusarium, such as elongation factor $1-\alpha$ and suggested the ITS region as a potential universal code for the identification of fungi. The ITS region was considered efficient in the identification and separation of Fusarium (MENEZES et al., 2010). Molecular markers, ITS and tefl, are considered fast and low cost practical tools for efficient discrimination and identification of Fusarium spp. (ARIF; CHAWLA; ZAIDI, 2012).

According to macroscopic and microscopic characteristics of the fungal colonies, F1UFSM was allocated to the section Liseola while F2UFSM was framed in the section Elegans; these sections are distinguished 
Table 2 - Mean values of emergence speed index (ESI), emergency (E), non-germinated seeds (NGS) and symptomatic seedlings (SS) of Pinus spp. seeds (Lot1, Lot2, Lot3, Lot4 and SP1) after inoculation with Fusarium spp. (F1UFSM and F2UFSM)

\begin{tabular}{|c|c|c|c|c|}
\hline \multirow{2}{*}{ Lot $\mathrm{x}$ isolates } & \multicolumn{4}{|c|}{ Variables } \\
\hline & ESI & $\mathrm{E}(\%)$ & NGS $(\%)$ & SS $(\%)$ \\
\hline P. elliottii Lot1 X F1UFSM & $5.33 \mathrm{~b}^{*}$ & $38 \mathrm{~b}$ & $62 \mathrm{~b}$ & $50 \mathrm{a}$ \\
\hline P. elliottii Lot1 X F2UFSM & $4.73 \mathrm{~b}$ & $36 \mathrm{~b}$ & $64 \mathrm{~b}$ & $63 \mathrm{a}$ \\
\hline P. elliottii Lot 1 - Control & $16.3 \mathrm{a}$ & $78 \mathrm{a}$ & $22 \mathrm{a}$ & $11 \mathrm{~b}$ \\
\hline \multirow{2}{*}{ Lot $\mathrm{x}$ isolates } & \multicolumn{4}{|c|}{ Variables } \\
\hline & ESI & $\mathrm{E}(\%)$ & NGS (\%) & SS (\%) \\
\hline P. elliottii Lot2 X F1UFSM & $9.3 \mathrm{~b}$ & $50 \mathrm{~b}$ & $50 \mathrm{~b}$ & $75 \mathrm{a}$ \\
\hline P. elliottii Lot2 X F2UFSM & $5.4 \mathrm{~b}$ & $39 \mathrm{~b}$ & $61 \mathrm{~b}$ & $57 \mathrm{a}$ \\
\hline P. elliottii Lot 2 - Control & $15.3 \mathrm{a}$ & $75.0 \mathrm{a}$ & $25 \mathrm{a}$ & $26 \mathrm{~b}$ \\
\hline \multirow{2}{*}{ Lot $\mathrm{x}$ isolates } & \multicolumn{4}{|c|}{ Variables } \\
\hline & ESI & $\mathrm{E}(\%)$ & NGS (\%) & SS (\%) \\
\hline P. taeda Lot3 X F1UFSM & $1.5 \mathrm{~b}$ & $18 \mathrm{~b}$ & $82 \mathrm{~b}$ & $10 \mathrm{a}$ \\
\hline P. taeda Lot3 X F2UFSM & $1.5 \mathrm{~b}$ & $12 \mathrm{~b}$ & $88 \mathrm{~b}$ & $13 \mathrm{a}$ \\
\hline P. taeda Lot3 - Control & $13.8 \mathrm{a}$ & $73.0 \mathrm{a}$ & $27 \mathrm{a}$ & $9.0 \mathrm{a}$ \\
\hline \multirow{2}{*}{ Lot $\mathrm{x}$ isolates } & \multicolumn{4}{|c|}{ Variables } \\
\hline & ESI & $\mathrm{E}(\%)$ & NGS (\%) & SS (\%) \\
\hline P. taeda Lot4 X F1UFSM & $2.05 \mathrm{~b}$ & $17.0 \mathrm{~b}$ & $83 \mathrm{~b}$ & $34 \mathrm{a}$ \\
\hline P. taeda Lot4 X F2UFSM & $3.02 \mathrm{~b}$ & $19 \mathrm{~b}$ & $81 \mathrm{~b}$ & $39 \mathrm{a}$ \\
\hline P. taeda Lot4 - Control & $9.65 \mathrm{a}$ & $64.0 \mathrm{a}$ & $36.0 \mathrm{a}$ & $21 \mathrm{a}$ \\
\hline \multirow{2}{*}{ Lot $\mathrm{x}$ isolates } & \multicolumn{4}{|c|}{ Variables } \\
\hline & ESI & $\mathrm{E}(\%)$ & NGS (\%) & $\overline{\mathrm{SS}(\%)}$ \\
\hline P. elliottii SP1 X F1UFSM & $18.3 \mathrm{a}$ & $81 \mathrm{a}$ & $19 \mathrm{a}$ & $32 \mathrm{a}$ \\
\hline P. elliottii SP1 X F2UFSM & $19.4 \mathrm{a}$ & $86 \mathrm{a}$ & $14 \mathrm{a}$ & $16 \mathrm{ab}$ \\
\hline P. elliottii SP1 - Control & $13.6 \mathrm{a}$ & $81 \mathrm{a}$ & $19 \mathrm{a}$ & $0.0 \mathrm{~b}$ \\
\hline
\end{tabular}

*Means followed by the same letter in the column do not differ by Tukey test at 5\% significance. Where: F1UFSM and F2UFSM are isolates of Fusarium spp. obtained from seeds of P. elliottii and Pinus taeda, respectively

according to the morphological similarities of the species (GERLACH; NIRENBERG, 1982; NELSON; TOUSSON; MARASAS, 1983) and provide a direction for the sequence during the identification process. The isolates F1UFSM and F2UFSM were identified as $F$. verticillioides (synonym $F$. moniliforme) and F. oxysporum, respectively. However, the confirmation of species was made possible only by the molecular determination (Figure 2). According to Leslie and Summerell (2006), the combinations of phylogenetic and biological concepts have a high potential for consistent characterization of the genus Fusarium. Furthermore, the use of molecular techniques for DNA analysis has allowed the development of fast, sensitive, and specific methods, complementary to the diagnosis of pathogens, for complementary to the morphological analysis (TEIXEIRA et al., 2004).
The pigmentation of the F1UFSM isolate was light beige in the PDA culture medium, while that of the isolate F2UFSM was violet (Table 3). The mycelial growth of both isolates was $12.85 \mathrm{~cm} \mathrm{day}^{-1}$, completing the Petri dish in seven days (Figure 3). Gupta, Misra and Gaur (2010) reported that $F$. oxysporum f. sp. psidii and $F$. solani showed maximum growth of $7.25 \mathrm{~cm}$ at $28^{\circ} \mathrm{C}$, after seven days of incubation. Skovgaard et al. (2003) recorded an average daily increase of $5.1 \mathrm{~cm}$ for the isolates of $F$. commune.

For variable sporulation in the leave-carnation-agar (LCA), it was observed that the isolate F1UFSM showed higher sporulation than F2UFSM what ranged from 11.25 $\times 10^{6}$ to $4.44 \times 10^{6}$ conidia $\mathrm{mL}^{-1}$, respectively (Table 3 ). Species of $F$. verticillioides produce sparse macroconidia 
Figure 2 - Phylogenetic dendrogram based on neighbor-joining method from the DNA sequences of the ITS region (A) and $1 \alpha$ Elongation factor (B). The numbers on the branches indicate the percentage of repetitions of the bootstrap analysis in which the repeats were observed (1000 repetitions). * Isolates of Fusarium spp. obtained in this study

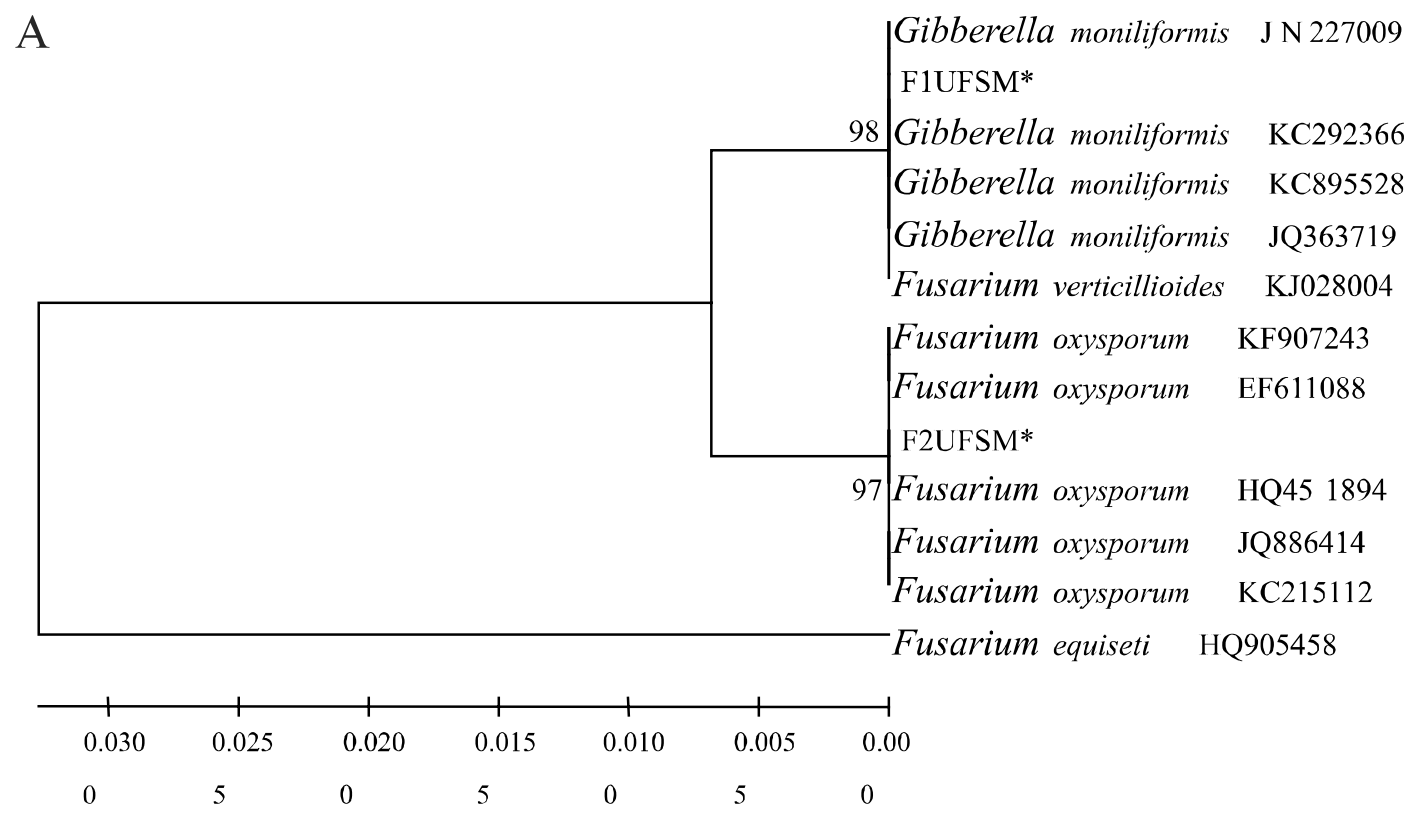

B

(2)

\begin{tabular}{|ll} 
Fusarium verticillioides & KF874614 \\
Fusarium verticillioides & KF994006 \\
Fusarium verticillioides & KF994005
\end{tabular}

KF874614

KF994006

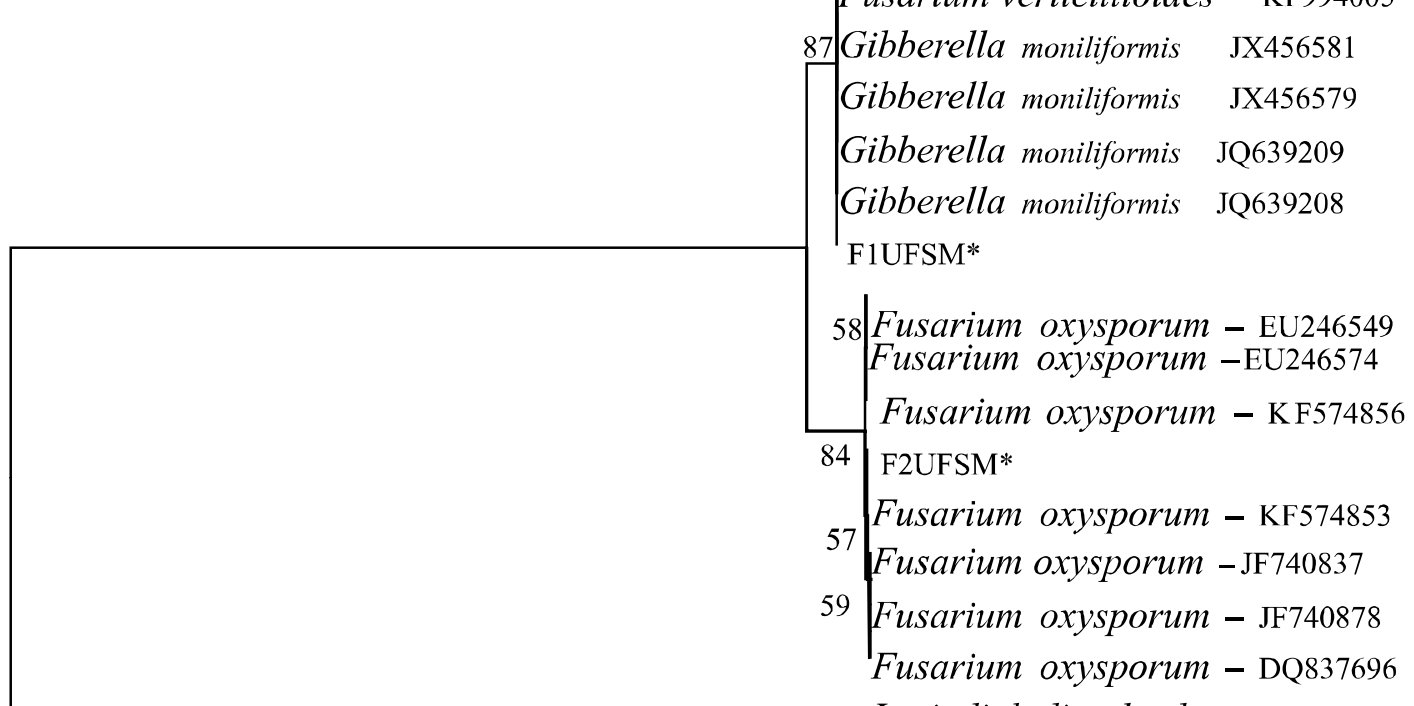

Lasiodiplodia theobromae FJ904845

0.1

while F. oxysporum has abundant production of these structures (LESLIE; SUMERELL, 2006). Silva and Teixeira (2012) found an average sporulation of $3.09 \times 10^{3}$ conidia $\mathrm{mL}^{-1}$ for $\mathrm{F}$. solani, using 12-hour photoperiod and PDA medium. On the other hand, Lazarotto et al. (2014), in tests with to the culture complex Gibberella fujikuroi on LCA culture medium, found high levels of sporulation, reaching $12.68 \times 10^{6}$ conidia $\mathrm{mL}^{-1}$ for one of their isolates (F5). The LCA medium favors the ultimate expression of the characteristics and sporulation of the genus Fusarium (NELSON; TOUSSON; MARASAS, 1983; VENTURA, 1999). 
Table 3 - Morphological characteristics of the Fusarium spp. isolates obtained of seeds from Pinus sp

\begin{tabular}{lcc}
\hline \multicolumn{1}{c}{ Characteristics } & F1UFSM Fusarium verticillioides & F2UFSM Fusarium oxysporum \\
\hline Color of colony $^{1}$ & Tone light beige & Tone violet \\
Measure of conidia $^{2}$ & (27.5) $36.9(42.5) \times(1.25) 2.7(3.75) \mu \mathrm{m}$ & $(10) 14.67(17.5) \times(2.5) 2.7(5) \mu \mathrm{m}$ \\
Shape macroconidia $^{2}$ & Long and slender; slightly falcate & Apical cell morphology short, slightly hook; basal cell foot shaped \\
Sporulation $^{2}$ & $11.25 \times 10^{6}$ conidia $\mathrm{mL}^{-1}$ & $4.44 \times 10^{6}{\text { conidia } \mathrm{mL}^{-1}}^{-1}$ \\
Presence of sporodochia $^{2}$ & + & + \\
Presence of microconidia & + & + \\
Presence of clamydospores & - & + \\
\hline
\end{tabular}

Potato dextrose agar culture medium, $25 \pm 2{ }^{\circ} \mathrm{C}$ and a photoperiod of 12 hours; ${ }^{2}$ Leave-carnation-agar culture medium, $25 \pm 2{ }^{\circ} \mathrm{C}$ and a photoperiod of 12 hours

Figure 3 - Regression analysis $(\mathrm{p}<0,05)$ to the colony diameter of $F$. verticillioides and $F$. oxysporum (F1UFSM and F2UFSM) on PDA incubated at $25^{\circ} \mathrm{C}$ and photoperiod 12 hours

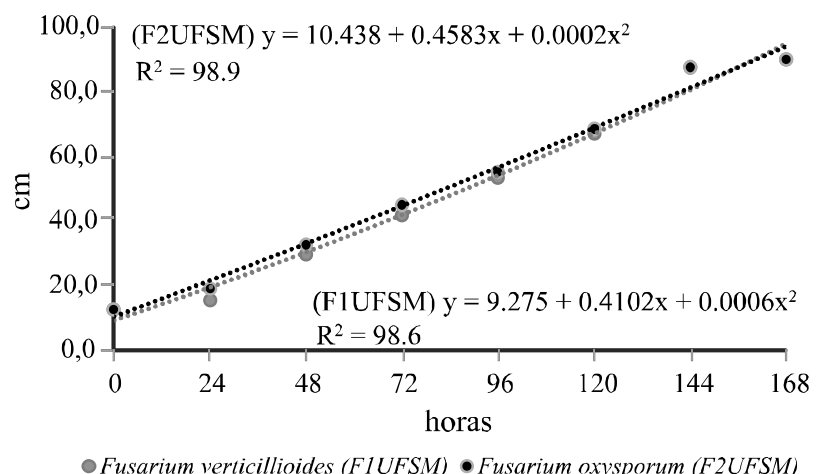

We believe that the present study contributes to the knowledge on the diversity and pathogenicity of $F$. oxysporum and $F$. verticillioides associated with Pinus seeds. Further analyses involving other Fusarium species associated with Pinus seeds would be beneficial to compare the differences between the species and their effects on the Pinus seedlings.

\section{CONCLUSION}

The Fusarium species identified were $F$. verticillioides and $F$. oxysporum and are pathogenic to $P$. taeda and P. elliottii, causing damping-off in pre-and postemergence.

\section{ACKNOWLEDGMENTS}

This work were supported by CAPES (Coordenação de Aperfeiçoamento de Pessoal de Nível Superior) Foundation (Brazil) and Conselho Nacional de Desenvolvimento Científico e Tecnológico (CNPq), project number 473722/2013-5.

\section{REFERENCES}

ALFENAS, A. C.; MAFIA, R. G. Métodos em fitopatologia. Viçosa: UFV, 2007. 382 p. BRASIL. Ministério da Agricultura, Pecuária e Abastecimento. Regra para análise de sementes. Brasília, DF, 2009. 395 p.

ARIF, M.; CHAWLA, S.; ZAIDI, N. W. et al. Development of specific primers for genus Fusarium and $F$. solani using rDNA sub-unit and transcription elongation factor (TEF-1 $\alpha$ ) gene. African Journal of Biotechnology, v. 11, n. 2, p. 444-447, 2012.

DELLAPORTA, S. L.; WOOD, J.; HICKS, J. B. A plant DNA minipreparation: version II. Plant Molecular Biology Reporter, v. 1, n. 4, p. 19-21, 1983.

FERREIRA, D. F. Sisvar: sistemas de análises de variância para dados balanceados: programa de análises estatísticas e planejamento de experimentos. versão 5.3 (Biud 75). Lavras: Universidade Federal de Lavras, 2010.

GEISER, D. M. et al. FUSARIUM-ID v.1.0: a DNA sequence database for identifying Fusarium. European Journal Plant Pathology, v. 110, n. 5, p. 473-479, 2004.

GERLACH, W.; NIRENBERG, H. The genus Fusarium: - a pictorial atlas. Berlin: Biologische Bundesanstaltfür Land und. Forstwirtschoft, 1982. 406 p.

GRIGOLETTI JUNIOR, A.; AUER, C. G. Fusariose em mudas de Pinus taeda. Colombo: Embrapa Florestas, 2006. 3 p. (Comunicado técnico 166).

GUPTA, V. K.; MISRA, A. K.; GAUR, R. K. Growth characteristics of Fusarium spp. causing wilt disease in Psidium guajava 1. in Índia. Journal of Plant Protection Research, v. 50, n. 4, p. 451-462, 2010.

LANDERAS, E. et al. Outbreak of pitch canker caused by Fusarium circinatum on Pinus spp. in Northern Spain. Plant Disease, v. 89, n. 9, p. 1015, 2005. 
LAZAROTTO, M. et al. Mycelia growth and sporulation of Fusarium chlamydosporum species complex under different culture conditions. Revista de Ciências Agrárias, v. 57, n. 1, p. 35-40, 2014.

LESLIE, J. F.; SUMMERELL, B. A. The Fusarium laboratory manual. 1. ed. USA: Blackwell Publishing, 2006. 388 p.

LORI, G. A.; SALERNO, M. I. Fusarium species on seeds of Pinus taeda L. and Pinus elliottii Engelm. in Argentina. Journal of Plant Diseases and Protection, v. 110, n. 5, p. 437-443, 2003.

MACIEL, C. G. et al. First report of Fusarium sambucinum associated on Pinus elliottii seeds in Brazil. Plant Disease, v. 97, n. 7, p. 995, 2013.

MAGUIRE, J. D. Speed of germination aid in selection and evaluation for seeding emergence and vigor. Crop Science, v. 2, n. 2, p. $76-177,1962$

MARTÍN-PINTO, P.; PAJARES, J.; DÍEZ, J. Pathogenicity of Fusarium verticillioides and Fusarium oxysporum on Pinus nigra seedlings in northwest Spain. Forest Pathology, v. 38, n. 2, p. 78-82, 2008.

MENEZES, J. P. et al. Variabilidade genética na região its do rDNA de isolados de Trichoderma spp. (Biocontrolador) e Fusarium oxysporum f. sp. chrysanthemi. Ciência e Agrotecnologia, v. 34, n. 1, p. 132-139, 2010.

NELSON, P. E.; TOUSSON, T. A.; MARASAS, W. F. O. Fusarium species: an illustrated manual for identification. Philadelphia: Pennsylvania State University Press, 1983. 193 p.

O'DONNELL, K. Molecular phylogeny of the Nectria haematococca-Fusarium solani species complex. Mycologia, v. 92, n. 5, p. 919-938, 2000.

OCAMB, C. M.; JUZWIK, J.; MARTIN, F. B. Fusarium spp. and Pinus strobus seedlings: root disease pathogens and taxa associated with seed. New Forests, v. 24, n. 1, p. 67-79, 2002.

PFENNING, L. H. et al. First report and characterization of Fusarium circinatum, the causal agent of pitch canker in Brazil. Tropical Plant Pathology, v. 39, n. 3, p. 210-216, 2014.
REHNER, S. A.; BUCKLEY, E. A Beauveria phylogeny inferred from nuclear ITS and EF1-a sequences: evidence for cryptic diversification and links to Cordyceps teleomorphs. Mycologia, v. 97, n.1, p. 84-98, 2005.

SCHMITZ, A.; RIESNER, D. Purification of nucleic acids by selective precipitation with polyethylene glycol 6000 . Analytical Biochemistry, v. 354, n. 2, p. 311-313, 2006.

SCHOCH, C. L. et al. Nuclear ribosomal internal transcribed spacer (ITS) region as a universal DNA barcode marker for Fungi. Proceedings of the National Academy of Sciences of the United States of America, v. 109, n. 16, p. 1-6, 2012.

SILVA, J. L.; TEIXEIRA, R. N. V. Esporulação e crescimento micelial de Fusarium solani em diferentes meios de cultura e regimes de luminosidade. Agro@mbiente On-line, v. 6, n. 1, p. 47-52, 2012.

SKOVGAARD, K. et al. Fusarium commune is a new species identified by morphological and molecular phylogenetic data. Mycologia, v. 95, n. 4, p. 630-636, 2003.

STEENKAMP, E. T. et al. Fusarium circinatum and pitch canker of Pinus in Colombia. Australasian Plant Pathology, v. 41, n. 5, p. 483-491, 2012.

TAMURA, K.; DUDLEY, J.; NEI, M. MEGA4: Molecular Evolutionary Genetics Analysis (MEGA) software version 4.0. Molecular Biology and Evolution, v. 24, n. 8, p. 1596-1599, 2007.

TEIXEIRA, H.; VIEIRA, M.; MACHADO, J. C. Marcadores RAPD na análise da diversidade genética de isolados de Acremonium strictum. Fitopatologia Brasileira, v. 29, n. 6, p. 651-655, 2004.

TSUI, C. K. M.; WOODHALL, J.; CHEN, W. Molecular techniques for pathogen identification and fungus detection in the environment. Ima Fungus, v. 2, n. 2, p. 177-189, 2011.

VENTURA, J. A. Taxonomia de Fusarium e seus segredos: parte I - história, meios e procedimentos de cultivo. Revisão Anual de Patologia de Plantas, v. 7, n. 1, p. 271-298, 1999.

WHITE, T. J. et al. Amplification and direct sequencing of fungal ribosomal RNA genes frophylogenetics. In: INNIS, M. A. et al. (Ed.). PCR Protocols: a guide to methods and applications. New York: Academic Press, 1990. p. 315-322. 